IIUC STUDIES

ISSN 1813-7733

Vol.- 9, December 2012

(p 161-186)

\title{
Causes and Consequences of Western Extreme Negativism against Islam - Will Such Negativism Ever End? How? Why or Why Not?
}

\author{
Ghyasuddin Ahmed Ph. D.
}

\begin{abstract}
Human bad manners of blame games, corruptions, crimes, deceptions, dislikes, greed, hate and turns and twists divide people and create most problems in the society. Since the beginning of industrialization human bad manners have increased many folds in recent years and perhaps reached the highest level resulting in the demise of Soviet communism in early 1990s and the free market economy or capitalism in 2008. After communism Islam became the undeclared enemy of the West that led to the tragic events of terrorism on September 11, 2001. No doubt such heinous acts are absolutely unacceptable and unjust, these gave the few most influential and powerful people in the West to demonize Islam and dehumanize the Muslims for their vested interests. These are the tiny 'invisible' interest groups of who come from different sectors of the society and they always benefit from societal chaos, conflicts, confusions and even wars. Justifiably the West went to war to punish and eliminate the terrorists ignoring totally the other side of story that made Muslim world hostile with the West - the Israeli and Palestinian conflict. This is the major cause of Muslim dissatisfaction around the world. To show their anger and dissatisfaction with the USA we saw people dancing and showing their happiness and joy on the streets in the Middle East immediately after destruction of the Twin Towers after the 911 attacks! The truth on Muslim anger was best enumerated by the Pew Research Centers and in a few interviews to the media by a top ranking ex-CIA agent, Michael Scheuer who was
\end{abstract}

${ }^{*}$ Faculty \& Sociology Program Coordinator, Dept. of Sociology, Social work and Criminal Justice, Virginia State University. 
assigned to monitor and track bin Laden. In one interview he says, "We have yet to find a politician who is willing to tell the American people the truth" on the causes that divide the Muslims and the West. Instead of seriously trying to resolve the differences between the Muslims and the West, those tiny but most powerful interest groups are heavily engaged - more openly in slandering and smearing Islam and have launched propagandas 24/7 to destroy any good images and names that Islam ever had. This paper discusses the causes and consequences of the prevalence of extreme negativism against Islam in the West through a theory that he calls the Residual Rules. Two systemic models have also been developed to show the various linkages that led to such extreme negativism against Islam. President Clinton's recent remark on the Middle East Conflict that Netanyahu killed the peace process and a large section of evangelical US Congressmen are making it impossible to end the conflict. The paper also raised many important issues and suggested few measures to improve relationships between the Muslims and the West.

Key Words: Extreme Negativism; Jefferson and the Quran; Residuals Rules Theory; Tiny Vested Interest Groups; Competing Religions; Invisible Coalitions; Muslim distrust; Jihad; Coercive Diplomacy; Women's rights; Presidents Carter \& Clinton, Scheuer.

\section{Backgrounds}

\section{Islam Before September 11, 2011}

Before the terrorist attacks on September 11, popularly known as 911 Islam was seen and relatively tolerated more positively in the USA but after these attacks Islam is now considered most negatively by the vast majority of the people not only in the USA but also around the world. The following are few positive aspects about Islam in the USA, since its independence more than two hundred years ago:

The founders of the US Constitution studied all major religious and legal histories of the world including that of the Holy Qur'an (or Koran/Coran). Thomas Jefferson, according to Hayes, 2004, (as well as George Washington) bought English translation of the Holy Quran ${ }^{2}$

2 After the spread of the news that Jefferson studied the Quran those who dislike and hate Islam started to flood the internet Websites with only one side of the story that 
(spelled as the Coran) to study Islamic Laws popularly known Sharia when Jefferson was a Law student at William and Mary College to study Islamic family laws (Hayes) [1].

Later Jefferson wrote the Declaration of Independence that included the provision equality between all human beings. This idea of Jefferson might have come from his in-depth study of the Quran. This is because the Old Testament or Taurat made the Jews as the only chosen people of God, while the New Testament or Injil considers 'Eve' as the original sinner that brought us in this corrupt and tempted world from the Heavens. This makes women inferior to men in Christianity. Contrary to the above inequity clauses in the Old and New Testaments, the Holy Quran most explicitly made equity, fairness, freedom, and justice for all as the basic Islamic ideals but very few people know or admit this obviously either to benefit from their views due to dislikes, egos and lack of knowledge on or about Islam.

Jefferson also used the Quran to know more about Islamic culture and laws in his dealing with the North African blockade in collecting 'bribe' or fees from the Americas and the Europeans [2].

Ironically the Declaration of Independence was recognized by the founders of the US constitution but equality between people was not given to the minorities for nearly 200 years after the declaration. Only the Social Revolution, successfully led by the late Reverend Martin Luther King. Jr. changed the situation towards equality between races. Islam however remains attractive to many people because of its provisions of equity, fairness, justices, peace, righteousness, simplicity and tolerance. Whether or not all or few followers of Islam practice these provisions are different - one always finds differences between idealism and its practices by people of all backgrounds - irrespective of age, ethnicity, race, religion or any other backgrounds.

he bought the Quran as a preparation to go to war with the North African countries as they were involved in piracies with Western Ships passing beside Muslim territories. They are totally ignoring the fact that Jefferson bought the Quran when he was a law student. According to Hays he also bought an Arabic Quran to learn the language. No doubt Hays made a very negative comment on Jefferson's classification and treatment of Islam, his paper provided many positive information of why Jefferson really read the Quran. The first elected Muslim Congressman (Ellison) took the Oath of Office by holding Jefferson's copy that is preserved in the US Library of Congressmen. 
Because the Holy Quran challenges the Christians and Jews on the two basic principles (i.e. Jews as God's only chosen people and Eve as the original sinner) and the concept that Jesus as the Son of God are most contagious issues between these three religions. For these reasons some religious leaders in the West want Islam to be destroyed or eliminated and some of them openly show their anger by burning the Qur'an, making caricature of the Prophet Mohammed or openly declare that it is the "responsibility of America to destroy Islam" [3].

\section{Islam around the World after 9/11 Attacks}

Since these tragic events Islam is labeled and viewed by those who dislike and hate Islam as the most dangerous, militant, terrorist's and a violent religion. Some Muslims having very little and no knowledge on their religion take sides the people of other religions to demonize and criticize Islam! Now it almost stands alone against all major faiths - as if it is a "cult" and these people also say that Islam is not even relevant to the $21^{\text {st }}$ century post-modern world! Islam is labeled today as antidemocratic, anti-development, anti-modern education, anti-equal rights or anti-women's right and anti- to anything good in the society! The Sharia or Islamic law is labeled as most barbaric! All these are contrary to the basic ideals / tenets of Islam. Knowing the true ideals of Islam is utmost important and therefore obligatory to people of all faiths and more so by all educated and influential people around the World - the capitalists, educationists, intellectuals, media personalities, politicians, religious leaders and even those who do not even believe in any religion. Living and working with people of different or no faith requires one to know, tolerate and understand the true cultures and ideals of all background faiths and people. If we know the culture, religion and tradition of other people that will be true diversity - because 'knowledge is power'. Knowing other people, their culture, religions and traditions does not mean that one has to accept or practice those. However, it is needed for accommodation, assimilation, harmony and peace among and between different peoples in this global society. Because people lack knowledge on religion and more so they know very little, if any of Islam knowing the true ideals of this religion will remove the usual negativity against it. For this reason the vested interest groups of all walks of life take advantage of common people's ignorance to propagate ideals that are not true of all backgrounds. The vested tiny groups' propagate 24/7 (24 hours) to convert or make people to believe in whatever is propagated against any ideal, issue or problem. 
Fitting the Residual Rules Theory to Explain the Causes of Extreme Negativism against Islam

Because of few tiny groups' vested aims, goals, interests, missions, greedy-needy objectives Islam is extremely negativity portrayed by all possible ways by the interest groups. Misunderstanding against Islam therefore, remains high and it will remain as such as long as those groups' gain from such activities, efforts and wrongful deeds directly or indirectly benefits them. These few groups constantly abuse or use fear and scare tact against Islam that the Muslims are going to do harm or kill all non-Muslims or forcefully convert them to Islam or will establish Muslim Sha'ria Laws in the West! In fact such residual groups mostly 'rule' the society directly or indirectly. In a normal curve the few people always reside at the two ends of the normal curve $\&$ these are the people rule the society directly or indirectly that I call the 'residual rules theory'. It is being analyzed and discussed in this paper. I have introduced this concept in 2002 while writing a research paper on 'police brutality, as perceived and experienced by the minority Students of Virginia State University. This I introduced as a theory in the Annual meetings of the Southern Sociological Society held in Atlanta, GA in 2004[4]. Since then I have used this concept to explain some other societal phenomena and most recently in the paper entitled "Human Bad Manners are Great Hurdles for President Obama to Bring the Changes He Promised” during his election in 2008 and presented it at the annual meeting of American Sociological Association's refereed roundtable held in August 2011 at Las Vegas, Nevada [5].

\section{How Residual Rules Theory [5] Works}

As has been stated before, only a tiny fraction of the total population of the country is usually responsible for bringing and initiating changes in the society. The two tiny groups of total population represent the extremely bad and the good; the negative or the positive or the non-righteous and the righteous humans in all societies and they reside at the two extreme ends of a normal curve - call the residuals. These residual people or entities gear and steer the vast majority of the people by their bad or good activities, deeds and manners that directly or indirectly rules the societies. The bad or wrong actions of people require the good people or management groups to make constitutions, laws, policies, regulations and rules to govern the groups, institutions, organization and societies. On one side reside the negative residuals those who are always busy in doing bad or wrongful acts or deeds that require the criminal justice systems. So, the actions of bad residual group necessitate the societies establish / make laws, norms, 
regulations and rules. For this reason I call this process as the residual rules theory ${ }^{3}$.

\section{Various Interest Groups’ Work against Islam}

The various tiny negative residual groups representing the economic, intellectual, media, political, religious (including sects) or social entities are constantly busy in doing harm or good to the common people. Such tiny groups' actions later become the common culture of the society as most people are too busy with their hustle and bustle of normal day today activities and do not have interest or time to know or validate what is being depicted, needed or said in the media by those interest groups. In reality these tiny vested interest groups become the breakers and makers of culture, norms, traditions and values - they even change or use the religious ideals that may not be supporting their corrupt and deceptive agendas. However, one should remember that there are good and bad people among all populations in all societies. Let us examine such groups' activities.

\section{Economic Groups - the Unfair Capitalists [See the Systemic Model A on Page 6]:}

Freedom is human nature (the wild self) as well as human manner (the socialized or rationalized self). So, the free market economy is both human nature as well as manner but any freedom must be come with responsibilities and this is when human natures split from human manners. Human manners are therefore, to be exercised most cautiously and responsibly to keep the tempted people away from doing wrongful acts that not only harm the general masses but also the 'bad guys'.

For this reason societies make constitutions, laws, norms, regulations and rules to control the greedy-needy selfish desires, goals, interests, natures, temptations and wants. Because of the 'tempted unholy human

3 Abbott Ferris, a sociology professor of Emory University asked the same question that people have been asking about the Functional Theory that it was developed without any formal research. My reply to the audience was current events or phenomena can be explained or theorized as they unfold without any formal research through obtrusive, personal or 'empirical observations' in the media or professional discourses and interactions. However, this concept was recognized while writing the research report on 'police brutality'. For a tiny few brutal policemen the whole police force gets the blame. The audience seemed to be satisfied with the answer as there was no counter question or discussion. 
manners' the free market capitalism failed in 2008. Even after the failure of capitalism such 'practitioners of freedom without responsibility' are arguing or insisting that there should be no regulations and regulators. If regulations and regulators are in place and those are implemented we would not have ended up with all economic messes found in most advanced societies. Regulations and regulators are needed to check our corrupt, deceptive and irresponsible behaviors in all societies. We only want to make money or wealth by all possible means but are forbidden to use illegal paths to achieve such goals or success. Unfortunately such regulations even do not stop those who only want to adventure or take chances so that they cannot be caught or they use corrupt means to evade laws, regulations and rules to gain money, resource and wealth by all possible means. For this reason the Holy Quran, Chapter 84 (Dealing with Fraud) opens up with such bad human manner,... 'Woe to those that deal with fraud, those who, when they have to receive by measure from men, exact full measure, but when they have to give by measure or weight to men give less than due' (84:1-3) [6a].

Due to lack of knowledge most people do not agree or know or understand that Islam is pro-capitalism, pro-democratic, pro-modern or even pro-secularism ${ }^{4}$ or even socialism. Islam does not prohibit people to become rich as long as it is achieved through most equitable, honest, just, responsible and righteous ways. According to Islam rich persons have to look after the well beings of all disadvantaged or poor people of the society. Islam, like all other religions forbids bribery, cheating, cooking of the books or corruptions, deceptions, gambling or making excessive profits or forbid taking or giving usury (popularly known as interest) or any other wrong doings of corruption, deception and unjust acts. Both righteous and wrong doing people are found in all religions. Therefore those who are righteous they always tend to follow that path but the super rich wrong doers do not like or want such righteous people because of their business and trade interests or goals. Containing the corrupt and deceptive wealthy is almost impossible in any society irrespective of religion or other backgrounds of the population of that society because money and wealth can buy almost anything or almost everything in this greedy-needy world. So, the

4 Religious tolerance is explicit in Chapter 2 Verse 256 and the whole Chapter 109. No doubt non-Muslims are critical of 'Jijia' tax levied to them they should know that Muslims are required to pay Zakat or poor taxes that is not obligatory to non-Muslims. 
economically dishonest and powerful people hate or do not want to see a religion that has many restrictions against their businesses (at times cheating or fake businesses), interests and trades - they would rather be happy if most people of all religions reject all or any restrictions that forbid them to earn as much as possible so as to sale their products or interests - even those that are forbidden in any religion.

Furthermore, faith in religion has weakened a lot around the world more so among the people who are intelligent, rich and want to acquire excessive profits and wealth illegally. Also because of their worldly success many rich people have little or no faith in religion or god as was the case in most societies where Prophets were sent - these are the people who rejected true faith and persecuted those who brought religions. In fact many use religion as a cover to do the wrongful acts through various means. Some (Muslims as well as others) even intentionally commit sins with the hope that in old ages they will repent and seek God's forgiveness as He is most Forgiving, Generous and most Merciful. So the practice of all wrongful acts is rationalized and used by different people in different ways.

Also, most Christians believe that their and Muslim God are two separate entities and Jesus took away the sins of his followers. This later concept is likely to be misunderstood by most common people in that they can do anything legal and illegal and Jesus will save them for any wrong deeds'! With such assurances some people are likely to violate the moral codes. Common sense understanding of this message clearly gives the wrong message that whatever and whenever anyone is engaged in sinful or wrongful acts, they are being saved by Jesus! The concept of Repentance is another factor that is abused or used by both Christians and Muslims to do bad or wrongful deeds that will be forgiven by God when repented. However, repentance and forgiveness are among the highest virtues in both these religions but very few people practice these ideals in their day today dealings. In fact revenge became a popular culture among most people around the world.

No doubt human dishonesties prevailed throughout human history it seems to have increased many folds in the recent times that also failed the two economic systems - the capitalism and the communism. The definition and concepts of chastity, equity, fairness, justice and morality are being abused, changed and used in all societies mainly due to greed and temptations. Greed and temptations first come in fulfilling the basic needs but later ends up in greed. Because Islam wants its followers to 
strictly follow its ideals or prohibitions that made the corrupt and the deceptive super riches in all societies. The increase of dislikes and hates of Islam and the Muslims clearly suggest that this religion is the target of those who benefit mostly from their dislike and hate. Anti-Islamic activities have increased many folds since the demise of communism and the West allowed few individuals to say or do anything against Islam under the cover of 'freedom of speech' without any regard to the fact that 'any freedom comes with responsibility, ("one's liberty ends where another person's nose starts"). In reality this definition of liberty is not being practiced by most people around the world. It is being used or abused depending on issues or problems at hand with most governments and people around the world. Any top executive (President or Prime Minister) of the government who is religious will let his / her 'diehard priests' and followers to do or say anything against other ideals or faiths behind the back of 'secularism', openly using appeasing rhetoric to their followers.

President W Bush's administration violated many principles of secularism against Islam and the Muslims. If the situation advantages the leaders and their 'diehard' followers the leaders will allow its followers to do anything to damage, destroy and harm the other ideals and their followers. His administration at times played the role of silent spectators but openly appeased the Muslims with rhetoric that Islam is a peaceful religion! If such leaders truly practiced freedom with responsibility the world would have been a much better or peaceful place. Therefore, our leaders do not hesitate to take cover of secularism totally ignoring the responsibility attached to it.

Most of these tiny deceptive groups are the unfair capitalists, and the same tiny competing religious groups in association with their allies are also demanding that Muslims must change Islam's Holy Book the Quran. In essence what they are indirectly demanding is to remove all prohibitions / restrictions so that their unfair market practices can easily be expanded or used throughout the world.

5 The protest marches in Islamic societies due to the demonization of Islam and demonization of its Prophets by few individuals, before and after the turn of the $21^{\text {st }}$ centuries, caused many deaths, destructions and loss of properties in Muslims countries. These are the examples of freedoms that were allowed or practiced without responsibilities that caused lots of harms to others!! 


\section{Model A: How and Why Extreme Negativism Against Islam Became the Culture - Theoretical Model.}

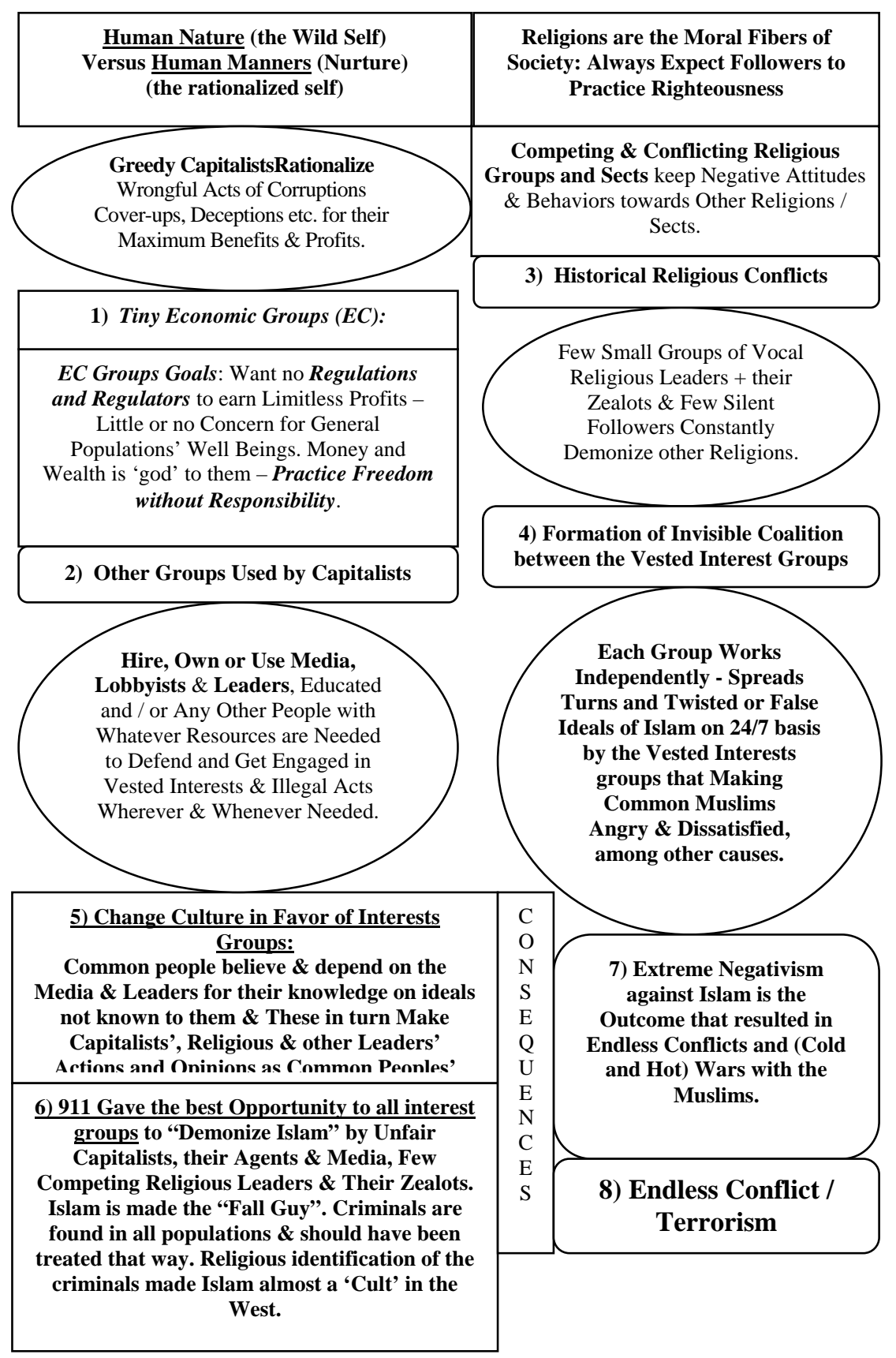


These powerful tiny groups also expect that everybody must ignore and overlook their unholy practices of blame games, cheatings, corruptions, deceptions and turns and twists on all of their other wrongful acts, behaviors and deeds. In other words they want such greedy, selfish and unholy acts should go unchallenged so that they can practice their deceptive acts and can take away every penny of the consumers by hook or by crook that consumers are currently earning or even will earn in endless future times!

\section{Other Groups Being Used by Capitalists:}

a) Highly Paid Loyal Agents: Economic power houses or the groups that practice 'governance of the rich, for the rich and by the rich (GOTRICH) behind the back of Lincoln's ideal definition of democracy (or government), use a tiny group of highly intelligent people who claim to be highly loyal, moral and extremely patriotic by arguing and presenting right facts to be fiction and false to be true. Their appealing arguments seem so plausible that many common people believe and support those tiny deceptive people. These hired individuals are busy 24/7 to demonize Islam and dehumanize the Muslims. These include a section of the media that become most popular as they are genius in making or telling right to be wrong and wrong to be right.

The "Lobbyists" also fall into this category - they are educated, intelligent, motivated and paid (by the vested interest groups) agents of the corrupt and deceptive Capitalists. But they are intellectually corrupt and immoral. They get engaged in influencing and motivating the leaders of economic, media, political and religious sectors so as to break and make laws, rules and regulation in their favor for maximizing their benefits and profits. President Obama is also failing due to the acts of these (agents, lobbyists and few 'one eyed' media) most corrupt and powerful actors' behaviors and their rhetoric. The honest or righteous people cannot operate like these wrong doers. This is because corrupt and deceptive actors are able to change societal cultures according to their likings and wishes.

\section{b. Personal or Hired Media and other Leaders for the Interest of the} Unfair Capitalists

Media is strong force that have changed culture and traditions of the society and some leading media are fiber of the society but the corrupt and unfair capitalists' and their invisible coalescent groups take it for guaranteed that all their wrongful acts must be tolerated by everybody, 
including their governments. So they demand for 'small governments' so that these people can continue to practice freedom without responsibility and continue to take away every penny of the common people's pocket forever as well as every penny the government treasury has. No wonder such 'deceptive and fake patriotic' people are allergic to regulations and regulators!

These collaborators or their henchmen act according to the guidelines and wishes of their employers. Therefore, econo-politico power houses that dislike and hate Islam or any other faiths or ideals act according to the vested interest groups' likings and wishes but not for the benefits of the nation or the common people. They usually fail when there is mass movements or revolutions that seem to have already begun - the 'Middle Easter or Arab Springs' and protest marches in Europe and it seems to be hatching in the USA too - most large cities are being occupied by angry protest groups who believe that GOTRICH people are most corrupt and deceptive. Print media has declined a lot and the most recent British media demise of Murdoch's is the best example. People are becoming fed-up with so many media that increase the cost of our living since the same advertisements are shown on many channels of the same owned media groups that increase the cost of products. So more and more media failure is likely and these communications may be taken over by Face Book, Internet, Twitter and all similar social media. These new media are probably going to eliminate the old and traditional media that dominated the society throughout the modern era. Therefore, breaking and making of individuals, culture, democracy or social networks or any other ideas or ideals are likely to be taken over by the social media of the future!

The demise of powerful media will change the characters of political landmarks and lobbyists of the country. Elections will be less costly and politicians will not be getting nor needing huge amounts of money to contest elections. Lobbyists will perhaps survive but it will also undergo changes reducing the extreme corrupt practices. Government regulations and regulators need to be more effective and efficient in all societies.

The demise of powerful media will change the characters of political landmarks and lobbyists of the country. Elections will be less costly and politicians will not be getting nor needing huge amounts of money to contest elections. Lobbyists will perhaps survive but it will also undergo changes reducing the extreme corrupt practices. Government regulations and regulators need to be more effective and efficient in all societies. 


\section{Competing Religious Ideals and Values}

There are serious conflicts between the three Monotheistic Religions, even though they have the same roots and many commonalities. According to the Holy Quran the Jewish claim of "God's only Chosen People" and the Christian concept of Trinity are not correct. Also Jews and Christians do not accept Prophet Mohammed (PBUH) as the Messenger of God. Conversion to Judaism is not acceptable to the orthodox Jews, while Islam and Christianity are competing religions. It will remain so and will be in conflict with each other as long as human beings live in this world.

So the religious leaders of these faiths wish that the other religions did not exist and will try to do anything - some with extremely negative agenda to destroy or eliminate the other religions. The tragic events of 9/11 gave the best opportunity to all religions to demonize Islam and dehumanize the Muslims. Also within each religion and its sects one finds different levels of intolerances between and within or outside of one's own faith.

The 9/11 events made all other religions to take Islam on and demonize it in any manner they or their agents can. Few Christian Priests came up openly and declared that "it is America's obligation to see that Islam is destroyed" (Presidential Candidate McCain's Priest Rod Parsley [3], during the 2008 Presidential election). He declared while McCain was present with him that Islam is a false religion and it is American obligation to destroy it! There are other Christian teleevangelists who constantly demonize Islam, 24/7 basis and narrate many stories that are not true of Islam but their convincing arguments, fake presentations and status make people to believe them.

Similar attitudes and behaviors were also observed among the Bush administration, including among his cabinet members during his eight years of Presidency. In fact Bush's slip of the tongue at the Islamic Center of Washington DC that the war on terror is a crusade created doubts about Bush's sincerity of purpose as he was a 'born again Christian' - the most anti-Islamic vocal group in the USA that wants to see the demise of Islam. His administration's use of illegal 'torture' was a ploy to make the Muslims fearful to practice their religions openly. It was a sign "Muslims be careful, you must not practice Islam and if you do you will face the same torture'. Torture was done violating American on legal principle of 'you are innocent unless proven guilty' - it was not the case with Muslim suspects and 
prisoners. Ironically the Bush administration also used the Muslim countries to 'torture' their own citizen without knowing whether or not those were guilty - what a irony!

There is no dearth of religious 'zealots' in any faith - they view Islam most negatively and will do anything to demonize or destroy Islam. These religious zealots and their leaders in the West that continuously insight the common people against Islam with rhetoric that it is a barbaric, false, militant, terrorist and violent religion. Some such zealots are also engaged heavily in the media to insight the public by misinterpreting the true ideals of Islam. Last but not the least there are also so called Muslims who do not know their religion and are convinced about the propagation against Islam by the West and hardly practice their faith. Such people also like to see that Islam is destroyed. In reality most of us also fail to appreciate and see that whoever follows whatever religion he / she find happiness and peace with that.

\section{Invisible Coalition of Interest Groups}

While demonizing Islam and dehumanizing the Muslims all groups have one common goal - to benefit from it. However, the economic groups, their agents, media and political leaders coalesce for the same monetary and other benefits and goals. All religious groups' goal is to get or recruit more people to believe in their religions. Also by recruiting more people in their religion the Priests will earn more income from their monthly contributions / donations. Together they form an invisible coalition, though work independent of one another. During this post modern period people are more engaged in entertainments and f.uns than spending times in some constructive or spiritual activities. Therefore, they mostly depend on the Churches, media and their leaders for education and knowledge on religion than from authentic sources. Also people trust their religious leaders for gaining knowledge about other religions and following their own religions. This last fact is the worst situation that a competing religion faces from the religious leaders of other religions as well as from the people who do not want to follow one.

Dislike of other cultures and religions is as old as human beings in spite of the fact that most religions have provisions of tolerance as their ideals. The discussions in the preceding pages provide clear ideas and information why Islam is demonized, disliked and misinterpreted intentionally to deceive and fulfill the powerful people's vested goals, interests and motives. Among all other hurdles religiosity prevents 
many - especially the people who follow Islam, not to consume / use many goods and services like alcohol, certain kind of foods, deceptive or fake goods and services, gambling and usury produced or provided by the unfair capitalists. For these reasons the same tiny residual and interest groups interpret or present Islamic ideology by quoting Quranic Verses out of context or by referring to a little or irrelevant verse or verses that do not carry the true messages of Islam.

Here is a small example of misinterpretation and misuse of Islamic ideals that I heard in the American media on Jihad. Quranic verses are usually quoted out of context by using less than even a single Verse (9:5) or even a lot of Verses (of the Chapter At-Tauba No. 9 Verses 1 16) and al-Bakara (2: 190-94) [6a. \& b] are to be used to truly understand the message(s) on the subject or topic. As we all know and remember that Quranic Verses are not like the 10 commandments, though the Judeo-Christian Ten Commandments are incorporated in the Holy Quran. Clearly such short hand explanations or interpretations are done to demonize the religion or to confuse people about Islam because most of those tiny residual groups want Islam to be destroyed or Muslims to leave Islam for the vested interest groups' goals, missions and objectives discussed throughout this paper.

\section{Conclusion [See Systemic Model B Page 12]}

\section{Reasons for not Winning the War on Terror}

Like the two sides of a coin terrorism also has two sides - the causes and the effects. President Bush recognized the affects only and waged wars against the actors, ignoring the other side of the issue without any serious attempt for its resolution of the causes of terrorism. It is done under the pretext of our (American) strategic and vested interests in the Middle East. The Bush administration thought that by fear and scare tact and by killing the so called terrorists (many of these people were peace loving innocent people caught by bribing some of the criminals of each country) it will be possible to 'the Muslim world' - the sophisticated word for it is: "neo-colonialism". He was also able to bring Pakistan on his side through 'coercive diplomacy' (Collins, 2008) [7] against the will of the common people of that country. So, we got an unwilling partner, Pakistan on American side but that made the war on terror more complex. Only after a decade it became clear now that coercion, fear, scare tact and even torture really do not work. This war also proved that committed but stateless entities, without any conventional weapons can 
keep the superpower and its allies engaged as long as they want through their Improvised Explosive Devices (IED)!!

However, some concerned and truly patriotic Americans tried to convince the Bush administration that we needed to address the causes of terrorism as well but Bush was firm in his belief and continued the wars resulting deaths and destruction to thousands of people on both sides that also drained trillions of dollars and probably the current economic crises in the USA as well as elsewhere.

Of the groups and individuals that tried to convince the Bush administration for taking actions on two fronts (i.e. causes and actions on terrorism) is the Iraq Study Group (or Baker-Hamilton Commission) representing one each an ex-Supreme Court Judge, an ex-Secretary of State, ex-Congressman and many other influential people [8]. President Carter [9] wrote a book on Palestinian rights and President Clinton recently (September 2011) remarked that Netanyahu killed the peace process. Clinton also believes that peace cannot be achieved because of the US Evangelical Christian Congressmen's stand that Palestine belongs to the Jews - making peaceful settlement impossible. He further said that 'those (the US) Congressmen that were over there (in Israel) and working with Netanyahu during the break at the time of his comment, that they're (US Congressmen) more militant than the orthodox Jews in Israel [10a \& b]. The ex-CIA agent responsible to monitor and track bin Laden, Scheuer [11 a \& b], enumerated the causes of Muslim dissatisfaction and the cause of terrorism against the West in one of the NBC Meet the Press interviews in 2004 and an another interview in 2006 with the "Frontline" Program of the National Public Radio entitled, "Spectacular Hypocrisy" on U.S. foreign policy in the Middle East (2006). In this interview Scheuer concluded:

"I also think the Israelis are wrong in not looking for a change in the relationship with the United States that would put it more in perspective -- that we are the great power, they are the minor power. I don't think there are a great many American parents who will want to sacrifice their soldiers and children so Israel can maintain the West Bank. 
When that becomes clear, I think Israel's days are numbered as an ally that is never questioned or criticized”.

At times the Bush administration talked about Muslim dissatisfaction with the West but did not do anything meaningful to remove such dissatisfaction - behind his back he was a born again Christian that wants to see Islam destroyed. Pew Research Center conducted time series research and found consistently that most Muslims are dissatisfied with the USA in terms of their attitudes and relations (Pew Research Center Reports from 2002 to 2011) [12]. Bush's actions and utterances probably angered more Muslims than with any other American President. However, he made a declaration for a two state solution of the Israeli and Palestinian conflict - the most important reason for Muslim dissatisfaction.

Coming to President Obama era - he has also failed to fulfill the promise he made at his inaugural address as well at the Cairo Speech that he would treat the Muslims with respect and try to resolve America's problems with the Muslim world. All these failures have also occurred due to the vested interest groups' concerted efforts. Resolving this conflict will diminish Muslim anger and acts of terror but we in the USA are living in complete denial about the causes and consequences of this straightforward problem.

Because we have failed so far to resolve this critical problem it is now taking the tool in terms of uprising - the 'Arab Spring'. If this trend continues and I believe it will, the sidelining of this problem by the USA will even be very costly for both the USA and the Israelis. I believe that the "Arab Spring" is the outcome of our policies in the Middle East. Youths will be playing greater roles in electing / selecting and running the future governments in the Middle-East and North Africa and our old policies will not be acceptable to the new leaders and rulers in Arab countries.

\section{Negativism against Islam is not Justified}

Some Islamic Ideals and Values that the vested interest groups criticize about, are: 1) Jihad; 2) Women's rights and status; 3) Islam's positions on other religions; 4) Islamic laws or Sharia etc.

1) Contrary to the common belief, rhetoric and understanding that Islam's Jihad is to kill all non-Muslims irrespective of age, gender or 
any other backgrounds the Holy Quran prescribes extreme caution and tolerance towards people of no or all faiths. In one Chapter (2: Verse 256) the Holy Book states, 'there is no compulsion in religion....' and a short Chapter (\#109) devoted to religious tolerance that states, 'you have your religion and I have mine' allowing people to practice any religion they choose. Jihad is an Arabic word and it has more than one meaning and the best is the 'lifelong striving' (22:78; 25:52; 29:69 \& $71: 11)$ so that one can remain steadfast and righteous in this tempted world. Jihad as holy war (2: 190-94 \& 9:1-21) occurs rarely while lifelong struggles are human companions that continuously follow us so as to lead a righteous life. To be righteous requires one to constantly be careful, have patience, tolerance, vigilance and the will to keep the actor away from all wrong doings like backbiting, blame games, cheating, corruptions, deceptions and temptations - to name a few. Following a righteous path is the goal of not only in Islam but in all established religions. From these perspectives life struggle is the best type of Jihad for Muslims because that will save them from doing bad or wrongful acts. However, Jihad as Holy War becomes mandatory when Islam or Muslims are oppressed, suppressed or thrown out of their homes (2:190-94) to defend and protect the believers and their religion. From this perspective the Palestinian struggle qualifies them for the Holy War. On the contrary, for common Muslims when asked to state whether they believe in Jihad, they cannot say no because everybody is striving to be on the righteous path in this tempted world. So, as soon as a person says that he or she believes in Jihad, those who extremely dislike or hate Islam, label the person as extremist and ready to 'kill any innocent people of all other religions'!! Clearly this labeling is wrong and probably intentional on the side of hate mongering people just to prove and show how bad the religion of Islam is. Jihad as holy war cannot be pre-emptive and it cannot be fought when such oppressions or suppressions stop. In religious wars Muslims are also asked to stop fighting when their enemy stops and if the enemy offers peace that must also be accepted by them, if and when such offers are just and equitable.

2) Coming to the question of Women's rights the West does not want to believe or know that of all the leading religions only Islam gave women the equal rights and the most practical status (2: 228) given to Muslim women some 1400+ years ago. So, when Muslims treat their women unequally it is not Islam that should be blamed - it is the bad mannered Muslims who are to be blamed. Islam is also the only religion that provides property rights to women, though there is controversy about the unequal shares sisters get that needs to be seen from the perspective of 
duties, obligations and responsibilities given to men and women in the society. In Islam man is made the provider and protector of all women in the family. So, when sisters get half the property or wealth compared to brothers they do not have any economic burden, obligations or responsibility towards the family. She can use her share of the property on anything she wants, while her brothers are to carry out all the economic, health, security and social burdens, obligations and responsibilities for all in the family. Women's incomes or wealth or the shares only belong to them and cannot be asked for by men until the women voluntarily give their share or wealth to anybody. Also, in marriage Muslim men are required to pay Mohr or 'dowry' (2:229, 236$37 \& 4: 4 \& 25)$ to the wife in accordance with the status or wealth of the 'would be husband' and this money can only be spent or used by the wife and cannot be taken back (4:20-21) by the husband. In other culture or religion dowry or bride price goes to the family or the husband. Polygyny or men marrying more than one wife $(4: 3)$ is not a free license to Muslim men - rather it is for honoring, respecting and providing shelters to disadvantaged women who might otherwise be mistreated by the adult males of the household [10].

3) Islam's Holy Book - the Quran treats the Jews and Christians with special reverence but it is totally ignored by those Christians and the Jews who demonize Islam and dehumanize its followers. Good Christians and Jews are called 'the People of the Book' meaning that their Bibles were revealed by the same God that Muslims Worship (2:62, 82 \&84). The vested interests groups pick up the Quranic messages that are directed towards the wrong doers, totally ignoring the many extremely positive messages in the Quran about Righteous Jews and Christians. The Quran also divides the Muslims into two groups - the Momin (the righteous Muslims) and the Monafiq (the hypocrite Muslims) who are going to get maximum punishment on the Day of Judgment - even more than those who associate partners with God. In other words the Quran recognizes that there are good and bad believers in all religions. These clearly suggest that it is better to be a 'non-Muslim' than a 'hypocrite Muslim'.

The Quran clearly states not to fight the Christians and the Jews on Small matters (29:46) but when they try to oppress or suppress Islam or throw the Muslims out of their homes the Muslims must defend themselves by fighting back and this is Holy War or the Jihad that is the greatest concern of the non-Muslims. Thus the Jihad is for self protection and not for harming and killing anybody of any faith or culture.

Living under the domain of one God means that we need to tolerate all human beings as God does - He protects and provides sustenance to all humans and other beings irrespective of castes, creeds or any other 
backgrounds. It is like an extended family under the head of one entity. Different members may pursue their ideals that make them different. If they want to live in peace and harmony they have to respect and tolerate one another's ideals. If they don't then conflicts and destructions are the outcome and this is what is happening between the people of different religions in spite of the facts that all religions have the provision of tolerance. When God tolerates everybody, as His vicegerents in this corrupt and tempted world human beings are to do the same.

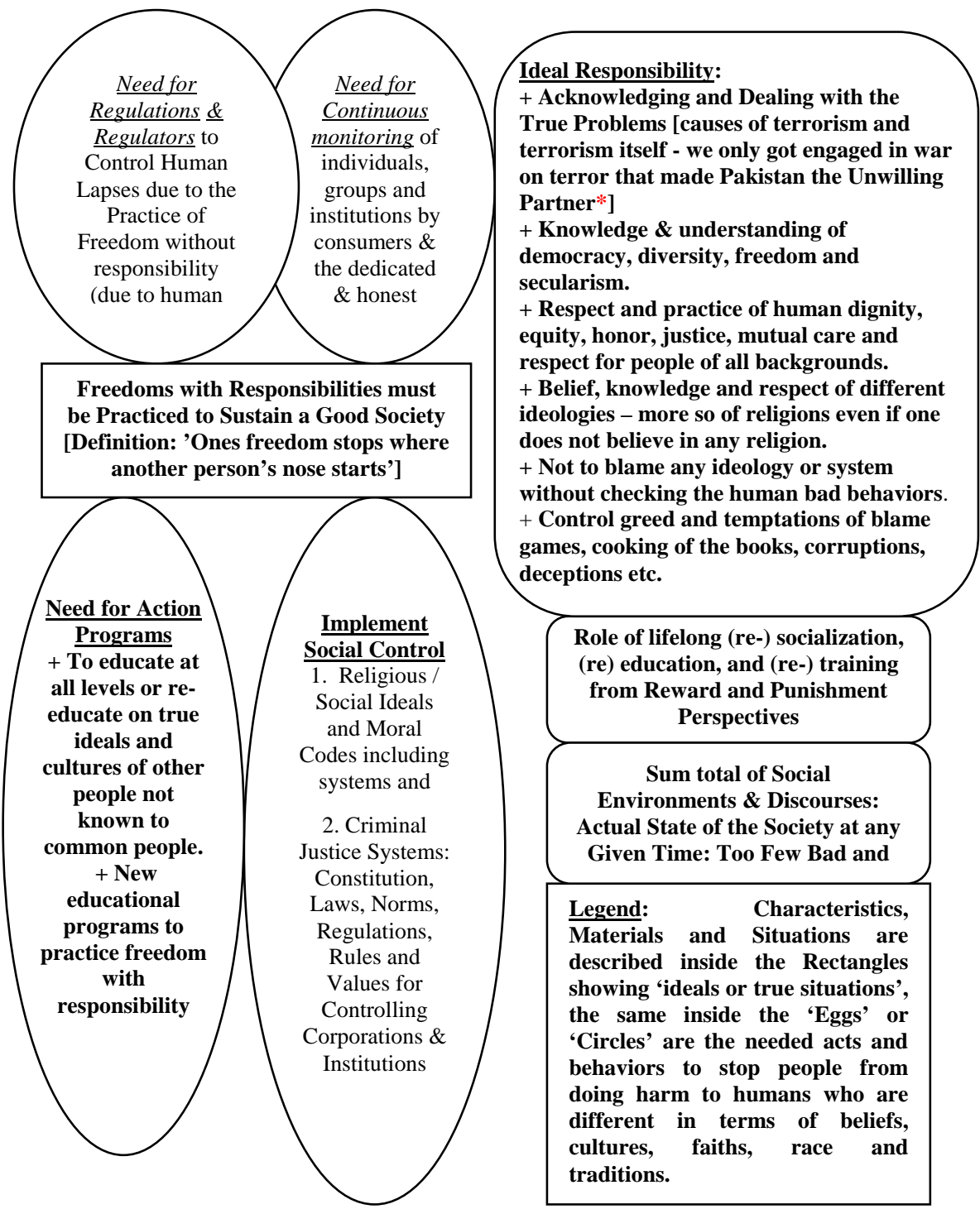




\section{Is it Possible to Change Negativism against Islam?}

a. Regulations and Regulators: Because the cheating and deceptive people always are busy in blame games, cooking of the books and turns and twists to achieve their hidden goals and tempted motives it is the responsibility of the governments to strictly control, monitor, regulate and implement the rules 'with iron fist' no matter how much they want to practice freedom irresponsibly. Strict adherence of laws, morals and regulations must continuously be carried out so that cheaters, corrupters and deceptive people are identified and prosecuted on regular basis. Any hidden corrupt, deceptive and hurtful agendas directed towards other people or organization must be continuously monitored, detected, investigated and taken care of by the Judicial system with the assistance and help of the regulators as well as the common people. It is clear that most influential and rich people do not want regulations and regulators so that they can continue to successfully implement their hidden agendas and corrupt and deceptive goals and practices through all possible means. If regulations can be strictly followed and implemented the wrongful activities of the tiny groups can be checked or stopped. But even this measure may not work if the regulators themselves are corrupt or could be influenced through bribery, corruptions, deceptions and nepotism of the vested interest groups as is the case with lobbyists in the USA. This will require another level of regulators and then another ... another... there will be no end to this cycle. In essence we have to have more than one check and balance points to find human rationalized bad manners at one of these levels, such corrupt and deceptive people will be caught and brought to justice.

b. Education - Both Formal and Informal: Knowledge is power but given the state of affairs with respect to Islam in the West most people will oppose any such attempt to introduce education on Islam but those who do not like this religion is likely to use the cover of secularism to stop any education on Islam or other ideals.

No doubt some higher educational institutions have already started courses on Islam and Arabic languages in the USA but their impact will probably be very little. However, something is better than nothing. In the field of sociology a courses on Sociology of Islam in all colleges and universities will be extremely helpful. Many sociology programs have a course on sociology of religion. Efforts must be made in these courses to compare and discuss all religions comparing the true ideals of all established faiths or even no faith. Extreme care needs to be 
taken while teaching these courses so that only true ideals are incorporated. Instructor's biasness must be controlled so that these courses do not become propagation tools of any religion. Even those who do not believe or practice any religion need to have minimum knowledge of all major religions so that people can practice diversity in its true perspective. I believe that studying the basics of all religions will bring better harmony, peace and tranquility between the people of different or no religion and that will be true diversity and will encourage people to show respect for people of all cultures, ideals, religions and traditions'. Today it is a global need to believe and practice true diversity in all societies. Also, education, through mass media, is likely to make better impact in the short run. But most media belong to those who dislike and hate Islam for their vested interests and this is the biggest problem to know and understand Islam better.

c. Need to Practice Secularism in its Right Perspectives: Secularism if practiced in its right perspectives will help reduce / remove some negativity and this will make some people to practice diversity in its right perspective. Interest groups and their agendas are the greatest hurdles to achieve or do anything the right ways and those are to be achieved, responsibly. For this reason we have the Criminal Justice system in place in all societies but when most people are misguided or misinformed justice cannot also be carried out the ways it to be practiced.

Like religion, the practice of secularism is also done in some irresponsible or wrong ways. And it occurs more when the top executives of the country are more religious minded, as was the case with President W. Bush - a born again Christian, and most of his cabinet and advisors. Secularists believe that governments should not be involved in any religious activities but unfortunately religion is being practiced behind the back of secular ideals when religiosity is strong among the governing group. Because most people $(85 \%+$ people of the world) believe in one or the other established religions and it is a part of most of these people's life. Therefore, governments have the responsibility to maintain harmony and peace between all people and this is diversity. In order to practice diversity all people should know the basics and basis of all religions of the world. People should rather be encouraged to know the true ideals of all religions because knowledge makes people to be more tolerant and understanding. True diversity will work better if people know one another's culture, religion and tradition. Lack of knowledge inhabits doubts, fears, dislikes and hatred between the people of different 
backgrounds and ideals and this is what is happening today, people are fighting one against the other religion without knowing what such conflicts bring dislike, disrespect, distrust and suspension between and among peoples.

Continuous and frequent interfaith dialogues and discourses are other means that also help to change peoples' negative attitudes and views about different cultures and faiths. Such activities have already been started among and between all religious in the USA, expect for those who keep extreme views against one or the other religion. Extreme views are usually formed either due to competition, envy and loss of gains and profits, as is depicted in the two System Models - A and B presented in this paper.

d. Violence Begets Violence: We know that violence and unjust acts bring problem and more violence. If we follow the true ideals of any religion we are unlikely to face any problem because most religions have the provision of tolerance but religious zealots do not follow such tolerances. Forgiveness is the highest virtue in almost all religions, Islam included. But people create agendas, issues and plans distorting their religion's true ideals or misinterpreting the messages so as to get maximum personal / corporate gains and profits out of such acts.

In a paper this author enumerated and discussed the various causes and consequences of terrorism and the action needed to control these and presented the paper in the 2007 "Peace Section" of the American Sociological Association's annual Conference [13] held at New York.

\section{Bad Rationalized Manners are Responsible for all Evils - There Cannot be a Utopian Solution}

Four simple words are utopian solutions - human beings will never achieve such solution and that is why this idea is an Utopia! The four simple words are: "practice freedom with responsibility". The practice of freedom with responsibility is missing in our selfish and tempted world. Human natures are wild, like all irrational animals' natures but human manners are polished selves $\left[5^{6}\right]$ that are modeled on the basis of the ideals of their cultures and those are learned. But we do not always follow the ideals that make our conduct bad or wrong and we

6 Clear distinctions between human natures and manners are made in the paper under Ref [5]. 
take such paths when we find that the true ideals cannot or do not let us fulfill the expected ambitions, goals or outcomes. However, the society always expects all human to do good or right or follow the righteous paths. But we have seen in this paper that some people do not follow good or right paths most of the times and most people at different stages of life also do something bad or wrong because of their convenience, greed, needs and temptations. Without rationalization people cannot practice wrongful deeds and once successful in achieving the desired goals with bad or wrongful deeds that become the culture of those who mostly tend to practice non-righteous acts. This way after achieving vast wealth such people also gain powers in the society and believe that money can buy anything and they behave that way. This had been the trend before and this will be the case in future but the difference in its magnitude has increased many folds over time. GOTRICH people will try to the hold their corrupt and deceptive cultures long as they can.

But they should look into the current worldwide econo-political-socioreligious environments and trends. We are fighting wars that have deep religious connections or connotations. Western economy is scrambling, 'Arab Springs' are changing the political dynamics, fields and environments in the Middle-East, and we have not been able win the hearts and minds of the Muslim as well as the wars on terror. More chaos, confusion, protests and even revolution are hovering around the world - more so around the advanced countries. Successes of globalization seem to have stagnated and at stake and if the world fails to contain the tiny vested interest groups' to practice their corrupt and deceptive methods of achieving more success and wealth, civil strife and revolutions are on their ways to invade the world. It will be best for them and for the good of the world if the GOTRICH people realize their mistakes and problems and bring back honesty and idealism into their business and other day today practices. Let us close our eyes and try to see the realities of how the home made Improvised Explosive Devices (IEDs) kept us - the only super power engaged in for a more than a decade and drained trillions of dollars but still we could not be victorious. This calls for true realization of the causes and consequences to take positive steps to resolve the true problems that are haunting us for too long - this is needed for better and peaceful world!!

The following Verses reveal; "They (non-Muslims) but wish that you (Muslims) should reject faith......".(4:89) and "The Unbelievers spend their 
wealth to hinder (humans) from the path of God, so they will continue to spend; but in the end they will have (only) regrets and sighs;......" (8:36); "their (non-Muslims') intention is to extinguish God's Light (religion) with their mouths: but God will complete His Light even though the Unbelievers detest (it)" (61:8).

Muslims find these verses as prophecies and the current extreme dislike, hatred and spending of resources to destroy Islam as the fulfillment of the above prophesies. We have spent trillions of dollars and have lost thousands of lives in wars but instead of destroying Islam more people are now accepting it. These seem to be fulfilling the forecasts made in the Quran that Islam cannot be destroyed - instead more and more people are now accepting it. So, some Muslims are also becoming more religious. However, few are also leaving Islam.

\section{References}

1. Hayes, Kevin J. 2004. How Thomas Jefferson Read the Qur'an. Early American Literature. Vol. 39, No. 2. Pp 247- 261.

2. Blumenfeld, Samuel L. 2010. Thomas Jefferson's Quran. New American. TNA Newletter. This is the counter view of why Jefferson bought the Quran (in response to President Obama's remarks during the Iftar Party at the White House given to Muslims).

3. Mother Jones Media. Corn, David. 2008. McCain’s Pastor Problem: The Video a taped Sermon by the Preacher (Rod Parsley) of Republican Presidential Candidate calls on Americans to see the "false religion" - Islam that must be "destroyed".

4. Ahmed, Ghyasuddin. 2004. Residual Rules Theory Combines the Functional and Conflict Theories. Paper presented at the annual meeting of the Southern Sociological Society held at Atlanta.

5. Ahmed, Ghyasuddin. 2011. "Human Bad Manners are Great Hurdles for President Obama to Bring the Changes He Promised” presented at the American Sociological Association's refereed roundtable held in August 2011 at Las Vegas, Nevada. Department of Sociology, Social Work and Criminal Justice, Virginia, State University (VSU), Petersburg. 
6. 6a. Ali, Abdullah Yusuf. 1989. Translation of the Holy Qur'an (Koran) with Arabic Original Qur'an. Durban, South Africa, Islamic Propagation Center International. [I have mostly used this translation that is published for the nonMuslim readers that replaced the word "Allah" to "God" for non-Muslim readers.]

7. 6b. Pickthall, Mohammed Marmaduke. 1994. The Meaning of the Glorious Qur'an. Falls Church (VA), Halalco Books. [I have also a copy of this translation - I might have used this translation in some quotations from the Quran]

8. Collins, Liam. 2008. United States Diplomacy with Pakistan Following 9/11: A Case Study on Coercive Diplomacy. WWS 547: The Conduct of International Diplomacy.

9. Baker and Hamilton Commission Iraq Study Group. 2006. Vintage Books - A Division of Random House, Inc., New York.

10. Carter, Jimmy. 2006. Palestine: Peace not Apartheid. Google eBook.

11. [10a] Clinton, William. 2011. Netanyahu killed the peace process. Roundtable with Bloggers on September day 22, 2011 (Posted By Josh Rogin).

12. [10b] Clinton, William. 2011. Clinton Links Perry's Views On Israel To 'Some of the More Militant Settler Groups’. MSNBC September 22, 2011. (By Ali Gharib)

13. [11a \& b] Scheuer, Michael. 2004. NBC's Meet the Press with Tim Russert, November 21 2004, and PBS Frontline Interview with Michael Scheuer. September 2006.

14. [12] Pew Research Center. 2002 - 2012. Pew Global Attitudes Project. There are numerous researches done by this center on American and Muslim relations and those are easily available in the Internet Site "Pew Research Center".

15. [13] Ahmed, G. 2007. Beyond the Baker-Hamilton Recipe for Honorable and Peaceful End of Iraq War and Other Related Conflicts - Sociological Theories of Endless Conflicts and Peace. Paper presented at the Annual Meeting of the American Sociological Association held at New York. Department of Sociology, Social Work and Criminal Justice, Virginia State University, Petersburg, Virginia. The paper can be found in the Web 'All Academic Research'. 